УДК 811.133.1’367

DOI https://doi.org/10.26661/2414-9594-2021-1-27

\title{
ЛЕКСИКО-СЕМАНТИЧНІ ТА ПРАГМАТИКО-СТИЛІСТИЧНІ ОСОБЛИВОСТІ ДІССЛІВ, ЩО ВВОДЯТЬ ПРЯМУ МОВУ, У ФРАНЦУЗЬКІЙ ПРЕСІ
}

\author{
Шемякіна Н. В. \\ кандидат філологічних наук, доцент, \\ дочент кафедри правничої лінгвістики \\ Начіональна академія внутрішніх справ \\ площуа Солом'янська, 1, Київ, Україна \\ orcid.org/0000-0002-3827-8505 \\ natalia-shemyakina@ukr.net
}

\author{
Ключові слова: \\ контекстуальні синоніми, \\ сема говоріння, лексико- \\ семантичне поле, \\ темпоральна семантика, \\ авторська оиінка, \\ гіперболізація, перлокутивний \\ ефект.
}

У статті розглядаються лексичний, семантичний, прагматичний та стилістичний аспекти дієслів, що вводять пряму мову. Як показує дослідження, пряма мова у французькій публіцистичній пресі вводиться перехідними і неперехідними дієсловами, які в основному передбачають процес говоріння. Серед цих дієслів найчастіше вживається дієслово "dire". Контекстуальними синонімами дієслова "dire" є: дієслова говоріння, які супроводжують мовленнєвий акт; дієслова, які вказують на особливості мовлення; фазові дієслова, які вказують на початок і кінець дії; ментальні дієслова, які вказують на розумову діяльність; дієслова, які не мають семи говоріння; дієслова фізичної дії; дієслова, які передають ставлення до слухача; дієслова, які вказують на психоемоційний стан особи під час мовлення. Вибір дієслова залежить від наміру автора, його оцінки прямої мови, що дозволяє йому вживати як нейтральні, так і експресивні дієслова, завдяки яким досягається перлокутивний ефект. Багато дієслів, що супроводжують пряму мову, мають у своєму значенні оцінний елемент та вживаються для досягнення стилістичного ефекту гіперболізації, з метою переконати читача.

У статті підтверджено, що дієслово, яке супроводжує пряму мову, уживається переважно в теперішньому часі, подає найчастіше минулі події як об’єктивно реальні з погляду суб'єкта мовлення. Другою часовою формою за частотністю вживання $є$ passé composé. Автор статті вважає, що вживання imparfait $є$ одним зі стилістичних прийомів надання авторської оцінки. Під впливом екстралінгвістичних чинників imparfait зумовлює різну темпоральну семантику висловлювання. Futur simple уживається у значенні минулого часу, означає майбутні події в момент висловлювання, які стали на цей час минулими. Plus-que-parfait виконує функцію імпліцитного минулого часу, позначає закінчену дію на тлі теперішнього часу у прямій мові. 


\title{
LEXICO-SEMANTIC AND PRAGMATIC-STYLISTIC PECULIARITIES OF THE VERBS INTRODUCING DIRECT SPEECH IN THE FRENCH PRESS
}

\author{
Shemiakina N. V. \\ Candidate of Philological Sciences, Associate Professor, \\ Associate Professor at the Legal Linguistics Department \\ National Academy of Internal Affairs \\ Solomianska square, 1, Kyiv, Ukraine \\ orcid.org/0000-0002-3827-8505 \\ natalia-shemyakina@ukr.net
}

Key words: contextual synonyms, speech sema, lexical-semantic field, temporal semantics, author's assessment, hyperbolization, perlocutionary effect.
The article deals with the lexical, semantic, pragmatic and stylistic aspects of the verbs introducing the direct speech. According to the research, the direct speech in the French press is introduced by the transitive and intransitive verbs, which mainly provide the process of speaking. Among these verbs the verb dire is the most often used. Contextual synonyms of the verb dire are: the verbs of speech that accompany the speech act; the verbs that indicate the peculiarities of speech; the phrasal verbs that indicate the beginning and the end of the action; the mental verbs that indicate mental activity; the verbs that do not have speech sema; the verbs of physical action; the verbs that express the attitude to the listener; the verbs that indicate the psycho-emotional state of the person during the speech. The choice of a verb depends on the author's intention, his/her assessment of the direct speech that allows him/her to use both neutral and expressive verbs, due to which the perlocutionary effect is achieved. Many verbs that accompany the direct speech have an evaluative component in their meanings and are used to achieve the stylistic effect of hyperbolization, in order to convince the reader.

The article proves that the verb that accompanies the direct speech is used mainly in the present tense, often presenting past events as objectively real from the point of view of the subject of speech. The second temporal form of the verbs in terms of usage frequency is passé composé. The use of imparfait is one of the stylistic methods of expressing the author's assessment. Under the influence of extralinguistic factors, imparfait causes different temporal semantics of the expression. Futur simple is used in the sense of the past tense, meaning future events at the time of expression, which have become past ones at this time. Plus-que-parfait performs the function of the implicit past tense, denoting the accomplished action against the backdrop of the present tense in the direct speech.
У дослідженнях, присвячених дієсловам мовлення в романських та германських мовах, є різні класифікації цих дієслів. Наявні дослідження дієслів мовлення на матеріалі французької мови не дали їх усебічного висвітлення, оскільки були проведені в основному на матеріалі прози. Обмеження вивчення дієслів говоріння стилем художніх творів не сприяло повному розумінню їхньої ролі в різних функціональних стилях. Поза увагою залишався також їхній прагматичний потенціал. Актуальність обраної теми зумовлена загальною спрямованістю сучасних лінгвістичних досліджень на аналіз функціонування мовних одиниць 3 урахуванням не лише їхньої форми, але й особливостей функціонування в дискурсі з урахуванням комунікативних та прагматичних властивостей [1, с. 335]. У цьому дослідженні дієслова, що вводять пряму мову, аналізуються на матеріалі сучасних газетно-журнальних матеріалів, які натепер перебувають у центрі уваги багатьох лінгвістів, оскільки великим є вплив засобів масової інформації на суспільство.

Мета статті - визначити лексико-семантичні групи дієслів, що вводять пряму мову; проаналізувати прагматичні та стилістичні особливості вживання дієслів, що супроводжують пряму мову, у дискурсі сучасної французької публіцистики.

Огляд лінгвістичної літератури свідчить про те, що дієслова говоріння в різних мовах здавна привертали увагу багатьох лінгвістів. Так, у словнику французької мови К.А. Ганшиної, як відзначає М.М. Бобирєва [2, с. 23], подано більше трьох 
сотень дієслів, які позначають мовлення і які розподіляються нею на декілька семантичних груп: 1) дієслова мовлення, які характеризують його 3 погляду темпу, тону, інтонації, логічного зв'язку 3 попереднім висловленням; 2) дієслова, що позначають початок, кінець, повторюваність, тривалість дії (commencer, terminer, répéter, ajouter); 3) дієслова чуттєвого і розумового сприймання (penser, songer, s'étonner, se plaindre); дієслова волі (protester, insister, décider); 5) дієслова, які передають неартикульовані звуки (hurler, murmurer, balbutier тощо); 6) дієслова, що означають активні дії (faire, couper, tomber).

Дослідники, які вивчають слова автора, які супроводжують пряму мову у французькій художній прозі [3, с. 39-40], відзначають, що сема «говоріння» $є$ ядерною у парадигмі висловлення, а дієслово dire є найуживанішим серед цих дієслів. Більшості дієслів супутні сема «дії», «механічної дії», сема «крики тварин», сема «абстрактної дії», сема «дії, не зв'язаної зі звуковим оформленням».

Повнішу семантичну характеристику дієслів говоріння у французькій мові ми знаходимо у С.В. Тищенка [4], який виділяє власне дієслова говоріння dire i parler, у яких лексико-семантичне поле мовотворення є основним, та периферійні, або їхні синоніми (у дієслова dire - 65, у дієслова parler - 82), яким властиві також інші характеристики: прагмастилістичні, що характеризують інформатора й умови комунікації; реляційні (оцінні), якщо інформатор фіксує своє ставлення до описуваної ситуації [4, с. 11-16].

Можна погодитися 3 думкою про те, що дієслова, у яких відсутня сема говоріння, набувають оказіонального значення внаслідок прагматичного наміру автора [5, с. 9-17] з метою впливу на адресата в умовах контексту, нетипового для основного значення дієслова. Отже, адресант передає зміст мови, іiі форму, своє ставлення до неї, впливає на адресата, спрямовує його сприйняття.

Румунський дослідник Д. Добр [6, с. 29-40] поділяє дієслова, що супроводжують пряму мову, на дві групи. Це, по-перше, дієслова суб'єктивного сприймання й операціональні дієслова (penser, estimer). До другої групи він відносить дієслова за типом відносин між протагоністами мовного акту - перформативні, перлокутивні, операціональні (accepter, montrer).

У сучасній французькій пресі дієслова, які вводять мову автора, є в основному дієсловами, що передбачають процес говоріння. Найчастіше вживається дієслово dire. Його контекстуальними варіантами, під якими розуміють «кореферентні або наближені за змістом найменування, що виконують стилістичну функцію і беруть участь у реалізації естетичної функції» [ 7, с. 187] є:

- дієслова говоріння, які супроводжують мовленнєвий акт: énoncer, proclamer, répliquer, poursuivre, demander, affirmer, déclarer, témoigner, assurer, rétorquer, raconter, accuser, remarquer, observer, promettre, relever, préciser, souligner, répondre, ajouter, avouer, commenter, expliquer, supposer, répéter, annoncer, conseiller, relativiser;

- дієслова, які вказують на особливості мовлення: tempérer, hurler, tonner, ironiser, rager, glisser, maugréer, tempêter, fulminer, rigoler, s'amuser, déplorer, plaider, se gausser;

- фазові дієслова, які вказують на початок і кінець діiі: commencer, résumer, pointer, conclure, interrompre;

- ментальні дієслова, які вказують на розумову діяльність: penser, conclure, analyser, se souvenir, rappeler, résumer, détailler;

- дієслова, які не мають семи говоріння: écrire, sourire, estimer, s'étonner, s'interroger, noter;

- дієслова фізичної дії: faire, se défendre, lancer, afficher;

- дієслова, які передають ставлення до слухача: prévenir, confesser, menacer, avertir, confier, insister, approuver;

- дієслова, які вказують на психоемоційний стан особи під час мовлення: se réjouir, déplorer, se plaindre, regretter, se féliciter, renchérir, se consoler, s'inquiéter, préconiser.

Порівняння дієслів, що передають слова автора, у газетно-журнальній лексиці та даних дослідження семантичного поля 135 дієслів говоріння C.В. Тищенка дає можливість відзначити, що у пресі вживаються не всі дієслова, наведені С.В. Тищенком. Багато дієслів є синонімами дієслова dire: déclarer, avouer, indiquer, expliquer, affirmer, assurer, avertir, répéter, énoncer, raconter, prévenir, confier.

Серед дієслів - синонімів parler зі списку C.В. Тищенка трапляються: confesser, énoncer, avouer. Водночас багато дієслів, що вживаються як контекстуальні варіанти дієслів говоріння в мові преси, не зазначені в наведеному С.В. Тищенком списку [4, с. 11-16].

Авторська оцінка $є$ модусною категорією i пов'язана з уживанням дієслів: se réjouir, déplorer, tempêter, regretter, se féliciter, renchérir, tonner, rager, hurler, se plaindre, які мають у своєму значенні елемент оцінки. Наприклад:

1) "Il faudra bien un jour que la redistribution des fonds publics se fasse suivant des critères économiques et non plus claniques", tonne Jean-Guy Forcioli, directeur des affaires économiques de la chambre d'Ajaccio (Le Nouvel Observateur);

2) "Trop d'élèves sont encore assis à même le sol, faute de bancs", déplore la directrice, Nasrim Qayyam (Le Monde);

3) "Nous avons réussi à nous affranchir d'une culture dépensière”, a renchéri Philippe Auberger, rapporteur général du budget (Le Monde).

Оцінка автора спостерігається й у разі вживання дієслів: insister, avertir, accuser, afficher, prévenir, 
menacer, fanfaronner. Деякі дослідники вважають, що «вибір дієслова спрямований не на переконувальний вплив, а на навіювання, маніпулювальний вплив на адресата», на цій підставі вважають, що провідним аспектом прагматики є оцінка [8, с. 17], що дієслово може інтенсифікувати зміст прямої мови, отже, посилити вплив на читача.

Низка дієслів (tempêter, rager, tonner, hurler та інші) уживаються для досягнення стилістичного ефекту гіперболізації з метою переконати читача. Гіперболізація надає експресивного відтінку газетному стилю. Вибір дієслова залежить від наміру автора, від його оцінки прямої мови, що дозволяє йому вживати як нейтральні (dire), так і експресивні дієслова (fulminer), завдяки яким досягається перлокутивний ефект.

Виразність стилю спрямована на читача i досягається також завдяки вживанню дієслів у переносному значенні (fulminer, хімічний термін, означає «вибухати», «детонувати», «кидати вогнем-блискавицею»; дієслова afficher у значенні «виставляти напоказ», дієслів розмовної мови (rigoler - «сміятися», «жартувати»). Наприклад:

4) "Et à la peine le texte voté. Berscy annonçait qu'il rayait d'un trait de plume plus de 20 millards de dépenses, le budget ayant été calculé sur des hypotheses de croissance trop optimistes <...> "On a l'air ridicule!" fulmine aujourd'hui Laurent Dominati, député de Paris" (Le Figaro);

5) "A Brioude Jean- Pierre et Jacques ont plongé les mains pour fabriquer des couronnes et des baguettes, avant de se voir offrir le diplôme de l'Éducation nationale», rigolait Jacques Barrot, en soupirant: "C'est la France comme on l'aime, ça sent bon, on se sent bien"' (Le Figaro).

Варто зазначити, що процесні дієслова, що передають пряму мову, можуть супроводжуватися прислівниками: tranquillement, vertement, gravement, finalement, régulièrement, alors, tout d'un coup тощо, серед яких переважають прислівники способу дії, оскільки об'єктивний характер викладення супроводжується авторською оцінкою.

Уживання часових форм дієслів, що супроводжують пряму мову, у мові преси не відрізняється від даних В.Г. Гака [9, с. 111]. Виділяються найбільш уживані й маловживані часові форми. До змісту граматичного часу входить суб'єктивний компонент, який вказує на автора, на акт мовлення, на співвідношення часу події з моментом мовлення.

Дієслово вживається переважно в теперішньому часі (70\% речень), подає найчастіше минулі події як об'єктивно реальні $з$ погляду суб'єкта. У цьому разі можна говорити про стилістичне вживання теперішнього часу для передачі минулих дій [9, с. 111], що сприяє динамічності викладення.
Другою часовою формою за частотністю вживання є passé composé (20,2\% речень), що означає нещодавно минулу дію, попередню стосовно моменту, коли автор описує ситуацію та констатує факт. Наприклад:

6) "Il s'agissait en fait de symbolyser médiatiquement et publiquement les retrouvailles avec l'autre tronc commun qui s'était séparé en 1947", a affirmé Gérard Fossé, dirigeant de la Fédération de l'alimentation, en rappelant le Manifeste des 500 (Le Figaro).

Imparfait (4,7\% речень) вказує на тривалу дію відповідно до «теперішнього в минулому». Подія сталася в минулому і вживання imparfait $€$ одним зі стилістичних прийомів надання авторської оцінки факту. Наприклад:

7) "Cela fait plaisir de retrouver le goût de la victoire”, souriait Louis Fernandez après la rencontre (Le Monde).

8) "Il s'agit plus d'une télévision améliorée que d'un micro-ordinateur tronqué, d'une sorte de nec plus ultra du Minitel", déclarait la semaine dernière Ray Lane, numéro deux du groupe, de passage à Paris (Le Figaro).

Якщо вживання imparfait у реченні (7) пов'язано $з$ бажанням автора підкреслити тривалість діï, то в реченні (8) imparfait означає минулу дію і вживається замість passé composé. Завершеність дії підкреслюється семантикою дієслова (déclarer - термінативне дієслово), а також уживанням обставини часу "la semaine dernière".

Можна погодитись із висновками сучасних спеціальних досліджень, присвячених уживанню минулих часів, що imparfait може представляти дію двояко і під впливом екстралінгвістичних чинників зумовлювати «різну темпоральну семантику висловлювання, у чому виявляється ємність дієслівної форми, іiї гнучкість у реалізації комунікативних цілей мовця» [10, с. 139].

Futur simple (3\% речень) уживається у значенні минулого часу, означає майбутні події в момент викладу, які стали на цей час вже минулими. Наприклад:

9) "Les alertes pourtant furent chaudes. Après les médiocres élections cantonales en mars 1982 - "Les Français se sont dits: "Faut qu'ils apprennent un peu à vivre là-bas", commentera François Mitterrand"," (Le Monde);

10) "Décidée précipitamment selon les uns, mal maîtrisée selon les autres cette riposte muscle a mal tourné. Des jeunes gens venus des bidonvilles - manipulés par indépendantistes, diront certains - débordent les dockers, saccagent et pillent en règle une bonne quinzaine de magasins du centreville" (Le Point).

На можливість уживання futur simple у значенні passé simple вказував П. Імбс [11, с. 46]. В обох 
реченнях $(9 ; 10)$ дієслова commentera, diront мають значення futur de perspective, тобто вказують на минулі події під час викладу автора, але майбутні події стосуються тих, про які йшлося. Plus-queparfait (2\% речень) виконує функцію імпліцитного минулого часу [11, с. 126], позначає закінчену дію на тлі présent у прямій мові:

11) "Un vrai sport donnera occasionnellement lieu à un spectacle ennuyeux: là est toute la difference entre le sport et le cirque", avait-il finalement rétorqué aux critiques de Jacques Villenewe (Le Monde).

Plus-que-parfait "avait-il rétorqué" (11) означає попередню дію, що не стосується теперішнього часу у прямій мові, але є вказівкою на імпліцитне минуле, що підкреслює різницю, яка існувала між спортом та цирком.

Висновки. Дієслова, що вводять пряму мову, у французькій газетно-журнальній пресі діляться на дві категорії: дієслова, які передбачають акт говоріння, та дієслова, які не припускають його, проте $€$ контекстуальними синонімами дієслів мовлення. У цьому дослідженні представлено широкий спектр контекстуальних варіантів дієслова dire: дієслова говоріння; дієслова, які вказують на особливості мовлення; фазові дієслова; ментальні дієслова; дієслова фізичної дії; дієслова, які передають ставлення до слухача; дієслова, які вказують на психоемоційний стан мовця. Варто зазначити, що в газетно-журнальній публіцистиці вживаються не всі дієслова, що супроводжують пряму мову в художній літературі.

Дієслово зазвичай уживається в теперішньому часі в описовій функції, у passé composé, plus-queparfait, futur simple. Варто зазначити, що більша частина прикладів охоплюють дві часові форми: présent ta passé composé.

Проведене дослідження підтверджує тезу про свідомий підбір мовних одиниць для того, щоб переконати читача, привернути увагу до своєї думки, долучити до свого способу мислення; отже, превалює прагматична спрямованість уживання мовних засобів для впливу на сприйняття прямої мови читачем та вміння автора володіти цими засобами.

\section{ЛIТЕРАТУРА}

1. Шемякіна Н.В Особливості актуального членування вставних речень, які передають слова автора. Вісник Маріупольського державного університету. Серія «Філологія». 2018. Вип. 18. С. 335-342.

2. Бобирева М.М. О типологии предложения в современном французском языке. Москва : Наука, 1964. $216 \mathrm{c}$.

3. Николаева И.В. Структурно-семантическая характеристика включений предикативных единиц в современном французском языке : дис. ... канд. филол. наук: 10.02.05. Москва, 1986. 160 с.

4. Тищенко С. Лексико-семантическое поле глаголов говорения во французском языке : автореф. дис. ... канд. филол. наук: 10.02.05. Киев, 1990. 17 с.

5. Новицкая Е.О. Функционально-прагматический аспект контекстуального варьирования глаголов английского языка, вводящих прямую речь : автореф. дис. ... канд. филол. наук: 10.02.04. Москва, 1985. 24 c.

6. Dobre D. Discours direct. VS. Discours rapporté. Revue roumaine de linguistique. 1989. T. XXXIV. № 1. Р. 29-40.

7. Хованская 3.И. Стилистика французского языка. Москва : Высшая школа, 1984. 344 с.

8. Воронков В.В. Прагматический аспект текста англоязычной публицистической журнальной статьи : автореф. дис. ... канд. филол. наук: 10.02.04. Москва, 1991. 28 с.

9. Гак В.Г. Теоретическая грамматика французского языка. Синтаксис. Москва : Высшая школа, 1986. $220 \mathrm{c}$.

10. Лісова І.Г. Комунікативно-прагматична ємність минулих часів у текстах офіційно-ділового стилю (на матеріалі французької мови). Вісник Київського лінгвістичного університету. Серія «Філологія». 1999. Т. 2. № 1. С. 134-139.

11. Imbs P. L'emploi des temps verbaux en français moderne. Essai de grammaire descriptive. Paris : Klincksieck, 1960. 269 p.

\section{REFERENCES}

1. Shemiakina N.V. Osoblyvosti aktualnoho chlenuvannia vstavnykh rechen, yaki peredaiut slova avtora [Features of the actual division of parenthetical clauses, which convey author's words]. Visnyk MDU. Visnyk Mariupolskoho derzhavnoho universytetu. Seriia: Filolohiia. Mariupol: MDU, 2018. Vyp. 18. S. 335-342. [Ukrainian]

2. Bobireva M.M. O tipologii predlozheniia $v$ sovremennom frantcuzskom iazyke. [On the typology of a sentence in modern French]. Moskva: Nauka, 1964. 216 s. [Russian]

3. Nikolaeva I.V. Strukturno-semanticheskaia kharakteristika vkliuchenniakh predikativnikh edinitc v sovremennom frantcuzskom iazyke: dis. ... kand. filol. nauk: 10.02.05. Moskva, 1986. $160 \mathrm{~s}$. [Russian] 
4. Tishchenko S.V. Leksiko-semanticheskoe pole glagolov govoreniia vo frantcuzskom iazyke: avtoref. dis. ... kand. filol. nauk: 10.02.05 / Kievskii gosudarstvennyi universitet im. T.G. Shevchenko, Kiev, 1990. 17 s. [Russian]

5. Novitckaia E.O. Funktcionalno-pragmaticheskii aspekt kontekstualnogo varirovaniia glagolov angliiskogo iazyka, vvodiashchikh priamuiu rech: avtoref: dis... kand. filol. nauk: 10.02.04 / Moskovskii gosudarstvennyi pedagogicheskii institut im. M. Toreza, Moskva, 1985. 24 s. [Russian]

6. Dobre D. Discours direct. VS. Discours rapporté [Direct speech. VS. Reported speech.]. Revue roumaine de linguistique. 1989. T. XXXIV. № 1. P. 29-40. [french]

7. Khovanskaia Z.I. Stilistika frantcuzskogo iazyka [The stylistics of the French language]. Moskva: Vysshaia shkola, 1984. $344 \mathrm{~s}$. [Russian]

8. Voronkov V.V. Pragmaticheskii aspekt teksta angloiazychnoi publitcisticheskoi zhurnalnoi stati: avtoref. dis. ... kand. filol. nauk: 10.02.04 / Moskovskii gosudarstvennyi lingvisticheskii universitet, Moskva, 1991. 28 s. [Russian]

9. Gak V.G. Teoretichekaia grammatika frantcuzskogo iazyka. Sintaksis. [Theoretical grammar of the French language. Syntax]. Moskva: Vysshaia shkola, 1986. 220 s. [Russian]

10. Lisova I.G. Komunikativno-pragmatichna emnist minulikh chasiv u tekstakh ofitciino-dilovogo stiliu (na materiali frantcuzkoï movi) [Communicative and pragmatic capacity of the past in the texts of official business style (on the material of the French language)]. Visnik Kyivskogo lingvistichnogo universitetu. Seriia Filologiia. Kyiv, 1999. T. 2, № 1. S. 134 -139. [Ukrainian]

11. Imbs P. L'emploi des temps verbaux en français moderne. Essai de grammaire descriptive. [The verbal timetable in modern French. Descriptive grammar essay]. Paris: Klincksieck, 1960. 269 p. [french] 